\title{
PENGARUH PSIKOLOGI KONSUMEN TERHADAP KEPUTUSAN PEMBELIAN KEMBALI SMARTPHONE BLACKBERRY
}

\author{
Bunga Geofanny Fredereca dan Chairy \\ Universitas Tarumanegara Jakarta, email: cchairy@yahoo.com
}

\begin{abstract}
Repurchase decision is influenced by several factors, among others are, marketing stimuli (marketing mix) environmental stimuli, consumer characteristics, and consumer psychology. Previously, marketers were more interested in studying consumer response to marketing mix. This study investigated the influence of consumer psychology on repurchase decision. The independent variables of the research are motivation, perception, learning, and attitude. The dependent variable is the repurchase decision of the BlackBerry. Data were collected by distributing questionnaires to 200 BlackBerry smartphone users. Data analysis was performed using multiple regression. The results showed that there is only one variable (attitude) that has a significant influence on repurchase decision. Thus, marketers with limited budgets need to be more selective in allocating their funds, which is primarily should be intended to build and develop positive attitudes towards BlackBerry.
\end{abstract}

Keywords: Consumer Psychology, Motivation, Perception, Learning, Attitude, and Repurchase decision.

\section{PENDAHULUAN}

Alat telekomunikasi telah menjadi salah satu kebutuhan penting bagi masyarakat luas. Penggunaan alat telekomunikasi berupa telepon selular secara luas merupakan indikasi bahwa masyarakat tidak lagi memandang telepon selular sebagai sarana pemenuhan kebutuhan mewah, tetapi lebih melihat pada fungsi penting yang dimiliki oleh produk ini. Secara umum telepon selular digunakan untuk melakukan panggilan jarak jauh atau jarak dekat dengan teman, kerabat, atau rekan bisnis. Fungsi lain yang dimiliki alat ini adalah untuk mengirimkan pesan berupa pesan singkat atau yang biasa disebut dengan SMS (short message service), mengakses internet, merekam dan mengirimkan gambar maupun video, games, dan beberapa fungsi lain yang ragamnya menyesuaikan harga produk. 
Penggunaan telepon selular untuk mengakses internet mulai meningkat pada awal 2000an, dengan populernya telepon selular bernama communicator. Di masa itu telepon selular jenis ini merupakan gadget dengan kemampuan mengakses internet yang terbaik. Sejalan dengan perkembangan teknologi telepon selular dan pergeseran selera konsumen, maka para pengguna communicator mulai terlihat nyata bergeser ke BlackBerry pada 2008. Saat ini pengguna BlackBerry di Indonesia telah melebihi satu juta orang (www.swa.co.id, 27 Juli 2010). Penetrasi BlackBerry di Indonesia semakin kuat. Pelanggan yang menggunakan layanan BlackBerry semakin meningkat. Hal ini terlihat jelas dari persaingan sengit yang dilakukan antar operator penyedia layanan BlackBerry di Indonesia (www.kontan.co.id, 1 Februari 2010).

BlackBerry sebenarnya merupakan merk smartphone dengan kemampuan mengakses internet yang lebih baik dari pada generasi teknologi telekomunikasi selular sebelumnya. BlackBerry pertama kali diperkenalkan di Indonesia pada tahun 2004 oleh operator Indosat. BlackBerry memiliki kemampuan layanan push e-mail, telepon, SMS, menjelajah Internet, dan berbagai kemampuan nirkabel lainnya. Penggunaan gadget canggih ini begitu fenomenal belakangan ini, bahkan kemudian menjadi suatu kebutuhan untuk fashion.

Seperti yang telah disebutkan di atas BlackBerry memiliki kemampuan push e-mail yang belum dimiliki oleh gadget sejenis sebelumnya. Kemampuan ini dianggap sebagai keunggulan BlackBerry. Dengan push e-mail semua e-mail masuk dapat diteruskan langsung ke pengguna gadget ini. E-mail yang diterima juga telah mengalami proses kompresi dan scan di server BlackBerry terlebih dahulu, sehingga aman dari virus. Sebuah e-mail berukuran $1 \mathrm{MB}$, jika diterima melalui push e-mail dapat menjadi $10 \mathrm{~kb}$ dengan isi yang tetap. Dengan gadget ini, lampiran file berupa dokumen Microsoft Office dan PDF pun dapat dibuka dengan mudah. Pengguna BlackBerry tidak perlu mengakses internet terlebih dulu dan membuka satu persatu e-mail yang masuk, atau melakukan pemeriksaan e-mail baru. Hal ini dimungkinkan karena pengguna akan terhubung secara terus-menerus dengan dunia maya melalui jaringan telepon seluler yang tersedia.

Saat ini BlackBerry merupakan alat komunikasi yang lazim digunakan oleh kalangan professional untuk menunjang pekerjaannya, terutama mereka yang berusia muda, dan berada di kota besar (www.swa.co.id, 15 Juli 2010). Gadget ini menarik kaum muda terutama karena BlackBerry juga memiliki aplikasi situs jejaring sosial seperti Facebook dan Twitter. Selain itu, daya tarik lain yang diminati kaum muda adalah kemampuan untuk terus terhubung melalui media internet yang memungkinkan adanya koneksi chatting di Yahoo! Messanger, MSN, dan BlackBerry Messenger. 
Suatu produk yang dipersepsikan unggul oleh konsumen dan meraih tingkat penjualan yang tinggi dapat dikatakan berhasil saat ini. Namun keberhasilan ini tentunya perlu dipertahankan sehingga nasib BlackBerry tidak seperti produk communicator yang saat ini mulai ditinggalkan konsumen. Salah satu ukuran keberhasilan dalam pemasaran adalah kemampuan suatu produk untuk mempertahankan dan meningkatkan pangsa pasar (Kotler \& Keller, 2006). Salah satu ukuran agar pangsa pasar tetap dapat dipertahankan dan ditingkatkan adalah adanya pembelian kembali atau pembelian ulang produk atau merk yang sama. Goodwin dan Ball (2003) mengatakan pembelian kembali oleh konsumen sangat penting dalam mempertahankan profitabilitas dan keberhasilan suatu bisnis.

Penelitian ini ingin menyelidiki faktor-faktor yang memperngaruhi pembelian ulang produk BlackBerry. Menurut Kotler \& Keller (2006) keputusan pembelian suatu produk dipengaruhi oleh berbagai faktor yaitu stimuli pemasaran (bauran pemasaran), stimuli lingkungan (ekonomi, teknologi, politik dan budaya), kraktersitik konsumen (budaya, sosial dan personal), dan psikologi konsumen (motivasi, persepsi, pembelajran dan ingatan).

Mempertimbangkan bahwa produk BlackBerry saat ini banyak digunakan kalangan muda terutama karena faktor psikologis, maka penelitian ini membatasi diri hanya menyelidiki faktor-faktor psikologi yang mempengaruhi keputusan pembelian kembali konsumen atas produk BlackBerry. Faktor-faktor psikologi konsumen ini adalah motivasi, persepsi, pembelajaran, dan sikap.

\section{LANDASAN TEORI DAN PENGEMBANGAN HIPOTESIS}

Keputusan Pembelian Kembali

Menurut Kotler dan Keller (2006), titik awal untuk untuk memahami perilaku konsumen adalah melalui model stimulus - response seperti disajikan pada Gambar 1 di bawah ini:

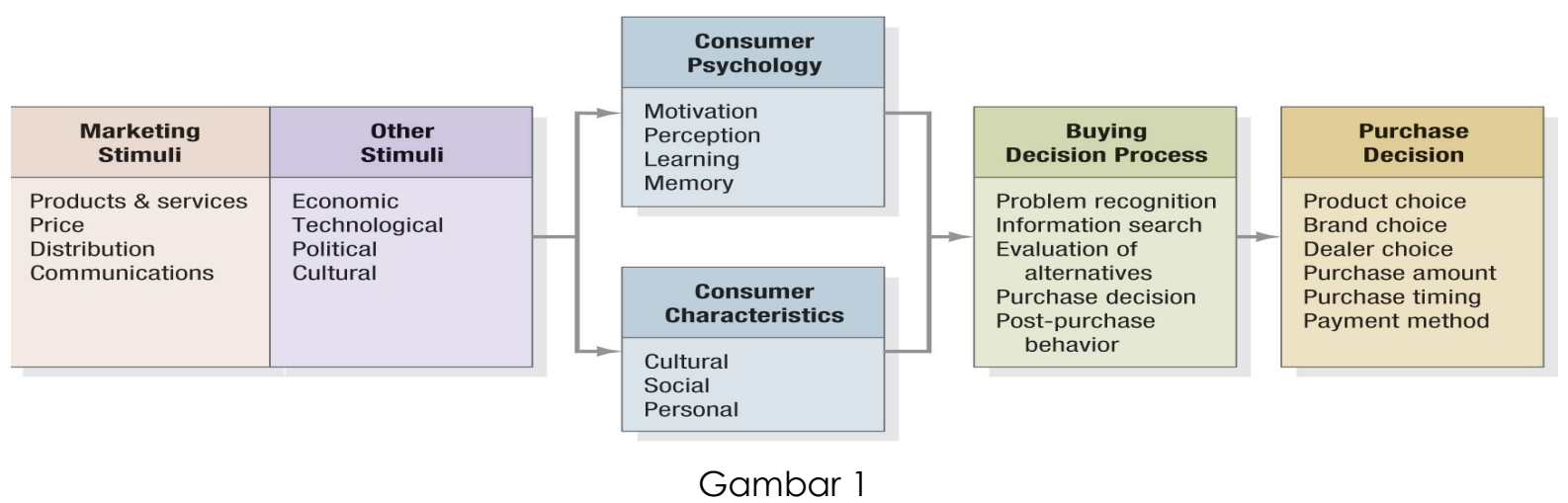




\section{Model Perilaku Konsumen}

Sumber: Philip Kotler \& Kevin Lane Keller. 2006. Marketing Management. Edisi 12, New Jersey: Pearson Education, hal 174.

Model perilaku konsumen di atas disebut model stimulus - response karena pada dasarnya konsumen memberikan respon terhadap stimuli yang diterimanya. Model ini diawali dengan stimuli pemasaran dan lingkungan yang diterima konsumen. Selanjutnya, serangkain proses psikologis dan karakteristik konsumen menentukan keputusan pembelian yang akan diambil seorang konsumen. Dalam proses psikologis terdapat beberapa faktor kunci yaitu motivasi, persepsi, pembelajaran dan ingatan, yang mempengaruhi respon konsumen terhadap berbagai stimuli pemasaran. Schiffman dan Kanuk (2007) menyebut berbagai faktor psikologi ini sebagai psikologi konsumen yang terdiri dari motivasi, persepsi, pembelajaran dan sikap. Penelitian ini akan menyelidiki pengaruh psikologi konsumen terhadap keputusan pembelian. Adapun faktor-faktor psikologi yang akan diselidiki dalam penelitian ini adalah elemen-elemen psikologi konsumen menurut Schiffman \& Kanuk (2007), yang akan dijabarkan pada sub bab berikutnya.

Keputusan konsumen dalam penelitian ini adalah pembelian kembali produk BlackBerry. Hawkins, Mothersbaugh, dan Best (2007) mengartikan pembelian kembali sebagai suatu kegiatan membeli kembali yang dilakukan oleh konsumen terhadap suatu produk dengan merek yang sama tanpa diikuti oleh perasaan yang berarti terhadap produk tersebut. Terdapat dua kemungkinan yang dapat menyebabkan seseorang melakukan pembelian kembali suatu produk. Pertama, konsumen merasa puas dengan pembelian yang mereka lakukan. Kedua, pelanggan merasa tidak puas, tetapi mereka tetap melakukan pembelian kembali. Hal ini disebabkan karena mereka menganggap biaya yang harus mereka keluarkan untuk mencari, mengevaluasi, dan mengadopsi produk dengan merek lain (switching cost) terlalu tinggi.

Blackwell, Miniard, dan Engel (2001) menyatakan pendapat yang sama yaitu sebagian besar pembelian akan terulang seiring dengan waktu. Ketika pembelian kembali muncul ada dua kemungkinan, yaitu pembelian yang diulangi dalam rangka memecahkan masalah (repeated problem solving), dan kebiasaan pengambilan keputusan (habitual decision making). Pembelian kembali pada habitual decision making dilakukan atas dasar kebiasaan atau rutinitas yang dapat mempermudah konsumen. Keputusan pembelian kembali merupakan salah satu keputusan pembelian konsumen yang diantaranya dipengaruhi oleh faktor psikologi konsumen. 
Sejauh ini telah terdapat berbagai penelitian tentang pembelian kembali. Umumnya pemasar tertarik untuk menyelidiki pengaruh stimuli pemasaran terhadap keputusan pembelian kembali. Berbagi produk telah diteliti dalam konteks ini, diantaranya mencakup berbagai produk seperti otomotif, kamera, peralatan fotografi, jasa restoran, dan jasa broker (Kim et al, 2003). Konsumen cenderung melakukan pembelian kembali untuk produk-produk ternama atau produk dengan merk yang telah dikenal luas terlepas dari apalah produk tersebut berharga mahal atau murah dan apakah produk high involvement atau low involvement (Akhir dan Othman, 2010). Penelitian ini diharapkan dapat melengkapi penelitian sebelumnya dengan menyelidiki keputusan pembelian kembali produk smartphone.

\section{Psikologi Konsumen}

Pengambilan keputusan konsumen sangat dipengaruhi oleh faktor konsumen sebagai individu. Solomon (2009) mengatakan bahwa dinamika internal individu yang walaupun "tidak terlihat" oleh orang lain, penting bagi semua orang. Tercakup di dalamnya adalah proses persepsi yaitu bagaimana individu menyerap dan menginterpretasi informasi tentang produk dan orang lain, proses pembelajaran yaitu bagaimana individu menyimpan informasi dan bagaimana informasi tersebut melengkapi pengetahun yang telah dimiliki sebelumnya, alasan atau motivasi individu untuk menyerap informasi tertentu dan bagaimana nilai budaya mempengaruhi apa yang seseorang kerjakan, dan bagaimana sikap terbentuk dan berubah serta mempengaruhi perilaku konsumsi. Schiffman dan Kanuk (2007) mengatakan bahwa psikologi konsumen berisi konsep dasar psikologi yang menentukan perilaku individu dan mempengaruhi perilaku konsumsi. Faktor-faktor dari psikologi konsumen dimaksud aalah motivasi, persepsi, pembelajaran, dan sikap konsumen.

Motivasi

Menurut Hawkins et. al. (2007) motivasi adalah kekuatan yang menggerakan seseorang untuk melakukan suatu aktivitas atau kegiatan yang mengarah pada perilaku yang diinginkan oleh seseorang tersebut. Mowen dan Minor (2002) mengatakan bahwa motivasi digerakkan oleh: (a) rangsangan, baik dari dalam maupun luar konsumen untuk mengubah suasana dan selanjutnya karena terjadinya perbedaan antara keadaan yang diinginkan dengan keadaan aktual maka akan menimbulkan kebutuhan; (b) pengenalan kebutuhan, yang terdiri dari kebutuhan ekspresif yaitu keinginan untuk memenuhi persyaratan sosial dan estetika dalam rangka pemeliharaan konsep diri seseorang dan kebutuhan utilitarian yaitu 
keinginan untuk menyelesaikan masalah yang mendasar; (c) dorongan, yaitu faktor yang membentuk keadaan afektif (emosi dan psikologis lainnya) yang mempengaruhi tingkat keterlibatan seseorang; (d) perilaku berdasarkan-tujuan, yaitu tindakan yang dilakukan untuk meringankan keadaan kebutuhan seseorang; (e) insentif konsumen misalnya produk, jasa, informasi, dan bahkan orang lain yang diperkirakan oleh konsumen akan memuaskan kebutuhan.

Pada dasarnya motivasi dibedakan menjadi: (a) motif rasional, dimana manusia berprilaku rasional pada waktu mereka mempertimbangkan alternatif dan memilih alternatif yang memiliki paling banyak kegunaan. Dalam konteks pemasaran, konsumen memilih produk berdasarkan kriteria yang objektif seperti ukuran, harga, berat, dan sebagainya.; (b) motif emosional, yaitu pemilihan berdasarkan kriteria yang subyektif dan bersifat pribadi seperti kebanggaan, ketakutan, perasaan maupun status. Hal ini berhubungan dengan kebutuhan sekunder atau bahkan tersier. Singkatnya, setiap tindakan konsumen memiliki alasan atau latar belakang. Dalam konteks penelitian ini, penggunaan dan pembelian kembali BlackBerry tentunya didasari oleh alasan tertentu yang dimiliki konsumen

Persepsi

Persepsi adalah suatu proses dimana seseorang memilih, mengatur, dan menafsirkan stimuli menjadi informasi yang dapat memberikan suatu gambaran mengenai sesuatu yang bermakna (Schiffman dan Kanuk, (2007). Persepsi adalah sesuatu yang berasal dari interaksi antara dua jenis faktor yaitu: (a) stimulus factors, yaitu karakteristik objek secara fisik seperti ukuran, warna, bentuk, dan berat. Tampilan suatu produk baik kemasan maupun karakteristiknya mampu menciptakan rangsangan pada indra seseorang, sehingga mampu menciptakan suatu persepsi mengenai produk yang dilihatnya; (b) individual factors, yaitu karakteristik yang termasuk di dalamnya tidak hanya terjadi proses pada panca indera tetapi juga pengalaman yang serupa dan dorongan utama suatu harapan dari individu itu sendiri. Solomon (2009) mengatakan persepsi melibatkan sistem indera manusia. Stimuli yang terdiri dari gambar, suara, bau, rasa, dan tekstur akan ditangkap oleh panca indera manusia yang terdiri dari mata, telinga, hidung, mulut, dan kulit.

Mencermati definisi persepsi di atas, terlihat bahwa persepsi merupakan proses tiga tahap yaitu melalui suatu urutan yang dimulai dengan eksposur, kemudian perhatian, dan diakhiri interpretasi. Eksposur terjadi ketika suatu stimulus diterima oleh konsumen. Perhatian adalah pemberian sumberdaya oleh individu kepada suatu stimulus. Interpretasi adalah arti yang diberikan oleh individu terhadap suatu stimulus yang diterimanya. Dengan demikian pemasar perlu melakukan berbagai usaha agar setiap tahapan dalam proses persepsi 
terjadi sesuai dengan yang diinginkannya. Pemasar perlu berusaha agar stimulus-nya (misal iklan) dapat diterima oleh konsumen (terekspos), selanjutnya konsumen memberikan perhatian terhadap stimulus dimaksud, akhirnya apa yang diintrepretasi konsumen terhadap stimulus pemasar adalah sesuai dengan yang dihaapkan pemasar. Secara singkat, pemasar dapat memanipulasi stimuli yang ingin diberikan kepada konsumen sehingga dapat ditimbulkan perrsepsi yang sesuai dengan keinginan pemasar. Dengan kata lain, melalui inderanya, konsumen dapat membentuk persepsi apakah suatu produk unggul ataukah sebaliknya. Dalam konteks penelitian ini, pengguna BlackBerry tentunya memiliki persepsi masing-masing terhadap produk ini.

Pembelajaran

Pembelajaran merupakan proses dimana para individu memperoleh pengetahuan dan pengalaman tentang pembelian dan berkonsumsi yang akan mereka terapkan untuk perilaku di masa yang akan datang (Schiffman dan Kanuk, 2007). Pada dasarnya terdapat dua pendekatan dalam pembelajaran konsumen yaitu: (a) pendekatan perilaku (behavioral approach) yaitu proses belajar yang terjadi karena respon konsumen terhadap suatu stimulus atau lingkungan konsumen; (b) pendekatan kognitif (cognitive approach), dimana pembelajaran dipandang sebagai penyelesaian masalah. Proses belajar kognitif adalah belajar yang dicirikan oleh adanya perubahan pengetahuan, yang menekankan pada proses mental (berpikir) konsumen untuk mempelajari informasi. Proses kognitif membahas bagaimana informasi ditransfer dan disimpan di memori jangka panjang (Blackwell, et al, 2001).

Dalam pendekatan perilaku terdapat dua konsep yang dikenal dan dipraktikkan secara luas dalam pemasaran yaitu classical conditioning dan instrumental conditioning. Classical conditioning terjadi apabila suatu stimulus yang dapat menghasilkan respon dipasangkan dengan stimulus yang tidak dapat menghasilkan respon secara berulang-ulang, maka selanjutnya stimulus yang tidak dapat menghasilkan respon pada awalnya kemudian dapat menghasilkan respon karena diasosiasikan dengan stimulus pertama yang dapat menghasilkan respon. Konsep ini yang menjadi dasar mengapa merk yang telah terkenal dapat dengan mudah memperkenalkan produk barunya dan sukses. Konsep yang kedua adalah instrumental conditioning yang menjelaskan mengapa seseorang bersedia melakukan sesuatu yang menguntungkan atau memberikan outcome positif bagi dirinya dan menghindari melakukan sesuatu yang memberikan outcome negatif. Solomon (2009) memberikan contoh, apabila seorang wanita memperoleh efek positif yang diinginkannya setelah menggunakan parfum "Obsession" maka di masa yang akan datang wanita 
tersebut sangat mungkin akan membeli kembali produk tersebut. Kasus yang sama dapat saja terjadi pda produk BlackBerry sepanjang konsumen memperoleh manfaat yang diharapkannya dengan menggunakan BlackBerry.

Dalam pendekatan kognitif, konsumen melakukan pengamatan terhadap perilaku orang lain yang memberikannya efek positif terhadap perilakunya. Dalam pendekatan ini, individu mengamati perilaku orang lain dan seolah-olah menjadi orang yang diamatinya. Pembelajaran cenderung terjadi bukan karena pengalaman langsung dirinya. Pengamatan terhadap orang lain yang memperoleh manfaat dari menggunakan BlackBerry dapat mendorong seorang individu untuk juga menggunakan produk yang sama.

Sikap

Sikap adalah evaluasi menyeluruh seseorang terhadap suatu objek yang dilihat atau yang dirasakan, yang kemudian memberikan sebuah kesimpulan mengenai objek tersebut (Solomon, 2009). Kesimpulan yang umum diberikan adalah baik atau buruk, menguntungkan atau tidak menguntungkan, dan positif atau negatif terhadap objek yang dievaluasi. Berdasarkan salah satu model sikap yaitu tricomponent attitude model, sikap terdiri dari tiga komponen utama yaitu komponen kognitif, afektif, dan konatif. Bagian pertama dari model ini terdiri dari kognisi seseorang, yaitu pengetahuan dan persepsi yang diperoleh dari kombinasi pengalaman langsung dengan obyek sikap dan informasi terkait dari berbagai sumber. Komponen kedua adalah afektif yang terbentuk dari emosi dan perasaan seseorang tentang objek tertentu. Komponen terakhir dari model ini (konatif) berkaitan dengan besarnya kemungkinan atau kecenderungan seseorang untuk berperilaku tertentu.

Dalam pemasaran, secara umum seseorang yang memiliki sikap yang positif terhadap suatu produk atau merk, maka orang tersebut akan memiliki kemungkinan yang lebih besar untuk membeli produk tersebut. Dalam konteks penelitian ini, dapat dipahami bahwa seseorang yang memiliki sikap yang positif terhadap BlackBerry akan memiliki kecenderungan yang lebih besar untuk melakukan pembelian ulang terhadap produk ini.

Hipotesa Penelitian

Penelitian ini menyelidiki intensi pembelian kembali produk BlackBerry yang merupakan variabel dependen. Adapun variabel dependennya adalah faktor-faktor psikologi konsumen yang terdiri dari motivasi, persepsi, pembelajaran, dan sikap. Berdadsarkan uraian 
teori tentang keputusan pembelian konsumen dan psikologi konsumen, maka dapat disusun hipotesa penelitian sebagai berikut:

$\mathrm{H}_{1}$ : Adanya pengaruh motivasi konsumen terhadap keputusan pembelian kembali produk smartphone BlackBerry.

$\mathrm{H}_{2}$ : Adanya pengaruh persepsi konsumen terhadap keputusan pembelian kembali produk smartphone BlackBerry.

$\mathrm{H}_{3}$ : Adanya pengaruh pembelajaran konsumen terhadap keputusan pembelian kembali produk smartphone BlackBerry.

$\mathrm{H}_{4}$ : Adanya pengaruh sikap konsumen terhadap keputusan pembelian kembali produk smartphone BlackBerry.

Adapun model penelitiannya disajikan pada Gambar 2 di bawah ini:

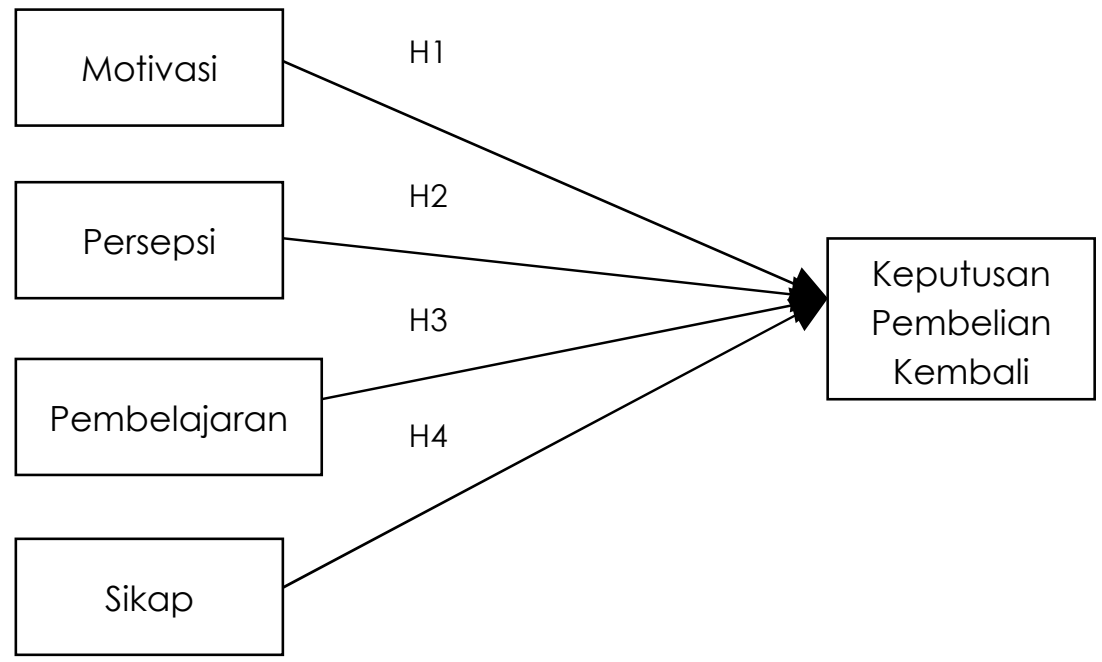

Gambar 2

Model Penelitian

\section{METODE PENELITIAN}

Populasi dan Sampel

Populasi penelitian ini adalah para pengguna BlackBerry saat ini. Mempertimbangkan bahwa mayoritas pengguna BlacBerry saat ini adalah kaum muda dan tinggal di perkotaan, maka sampel ditarik dari kalangan mahasiswa pengguna BlackBerry di salah satu universitas swasta terbesar di Jakarta. Teknik sampling yang digunakan adalah nonpropbability sampling, atau lebih spesifiknya convenience sampling. Hanya para mahasiswa pengguna BlackBerry yang berkenan meluangkan waktu mengisi kuesioner yang berpartisipasi dalam penelitian ini. 
Mengacu pada pendapat Aritonang (2007), maka jumlah sampel dapat didasarkan pada rata-rata ukuran sampel yang digunakan dalam studi-studi sejenis sebelumnya. Selain itu dapat digunakan pedoman umum yang lazim digunakan dalam penelitian multivariat yaitu jumlah sampel minimal 5 subjek untuk setiap indikator pada variabel independen yang di analisis. Berdasarkan pendekatan ini maka untuk sampel sebanyak 200 orang telah memenuhi praktek yang dilakukan dalam penelitian sebelumnya.

Dari ke-200 responden ini terdapat 83 responden laki-laki dan 117 responden prerempuan. Usia mereka bervariasi dari 17 tahun (mahasiswa semester pertama) sampai dengan 24 tahun (semester akhir). Uang saku mereka bervariasi mulai dari Rp. 500.000 per bulan sampai dengan lebih dari Rp. 2.000.000 per bulan, dengan mayoritas memiliki vang saku sebesar Rp. 2.000.000 sebanyak 79 orang atau sekitar $40 \%$-nya.

Pengembangan Kuesioner

Alat ukur yang digunakan adalah kuesioner multikotomis, dimana subjek memiliki lebih dari dua alternatif tanggapan atas pernyataan yang diajukan berupa sangat setuju, setuju, netral, tidak setuju, dan sangat tidak setuju (skala likert). Setelah masing-masing tanggapan diberikan bobot nilai maka semua pernyataan dapat dirubah dalam bentuk bilangan. Definisi operasional masing-masing variabel yang disusun berdasarkan hasil penelitian sebelumnya dan konsep perilaku konsumen kemudian dijadikan dasar untuk penyusunan kuesioner seperti disajikan dalam Tabel 1 di bawah ini:

Tabel 1

Operasionalisasi Variabel 


\begin{tabular}{|c|c|c|c|}
\hline No. & Variabel & Indikator & Skala \\
\hline 1. & $\begin{array}{l}\text { Motivasi }\left(\mathbf{X}_{1}\right) \\
\text { Suatu dorongan kebutuhan } \\
\text { dan keinginan individu yang } \\
\text { yang mengarah pada suatu } \\
\text { tindakan untuk memperoleh } \\
\text { keinginannya. } \\
\text { (Kotler dan Keller; 2006) }\end{array}$ & $\begin{array}{l}\text { Dorongan kebutuhan akan memiliki produk } \\
\text { Dorongan kebutuhan akan menggunakan produk } \\
\text { setiap saat } \\
\text { Dorongan untuk menunjang penampilan } \\
\text { Dorongan akan tren yang sedang terjadi di } \\
\text { lingkungan sosial } \\
\text { Dorongan kegemaran akan produk }\end{array}$ & $\begin{array}{l}\text { Likert } \\
5 \text { poin }\end{array}$ \\
\hline 2. & $\begin{array}{l}\text { Persepsi }\left(\mathbf{X}_{\mathbf{2}} \text { ) }\right. \\
\text { Sebuah proses yang diawali } \\
\text { dengan pemahaman } \\
\text { konsumen dan perhatian } \\
\text { terhadap rangsangan } \\
\text { pemasaran dan berakhir } \\
\text { dengan penafsiran } \\
\text { konsumen terhadap sesuatu. } \\
\text { (Hawkins,, et al, 2007) }\end{array}$ & $\begin{array}{l}\text { Pemahaman terhadap manfaat produk } \\
\text { Pemahaman terhadap variasi tipe produk } \\
\text { Pemahaman terhadap popularitas merek produk } \\
\text { Pemahaman terhadap keistimewaan produk } \\
\text { Pemahaman terhadap kegunaan produk }\end{array}$ & $\begin{array}{l}\text { Likert } \\
5 \text { poin }\end{array}$ \\
\hline 3. & $\begin{array}{l}\text { Pembelajaran }\left(\mathbf{X}_{\mathbf{3}}\right) \\
\text { Proses dimana individu } \\
\text { memperoleh pembelian dan } \\
\text { pengetahuan konsumsi dan } \\
\text { pengalaman yang berlaku } \\
\text { untuk perilaku di masa yang } \\
\text { akan datang } \\
\text { (Schiffman dan Kanuk; 2007) }\end{array}$ & $\begin{array}{l}\text { Informasi yang diperoleh dari pengalaman teman } \\
\text { Pengalaman diri sendiri } \\
\text { Informasi yang diperoleh dari penjual } \\
\text { Informasi yang diperoleh dari media } \\
\text { Konsumen memiliki pengetahuan tentang cara } \\
\text { menggunakan produk }\end{array}$ & $\begin{array}{l}\text { Likert } \\
5 \text { poin }\end{array}$ \\
\hline 4. & $\begin{array}{l}\text { Sikap }\left(\mathbf{X}_{\mathbf{4}}\right) \\
\text { Kecenderungan belajar } \\
\text { untuk berperilaku dengan } \\
\text { cara menguntungkan atau } \\
\text { tidak menguntungkan } \\
\text { secara konsisten terhadap } \\
\text { objek tertentu } \\
\text { (Schiffman \& Kanuk; 2007) }\end{array}$ & $\begin{array}{l}\text { Produk yang dibeli adalah produk yang terbaik } \\
\text { Produk yang dibeli merupakan produk terkenal } \\
\text { Produk yang dibeli adalah produk yang diinginkan } \\
\text { Produk yang dibeli adalah produk yang disukai } \\
\text { Produk yang dibeli adalah produk yang handal }\end{array}$ & $\begin{array}{l}\text { Likert } \\
5 \text { poin }\end{array}$ \\
\hline
\end{tabular}

Kuesioner yang disusun selanjutnya mengalami beberapa kali uji coba sampai dipenuhi syarat valid dan reliabel. Hasil uji validitas dan realibilitas menghasilkan nilai corrected item total correlation untuk semua indikator pada masing-masing variabel dengan nilai lebih dari 0.3 dan nilai cronbach alpha untuk masing-masing variabel lebih besar dari 0.7 (motivasi $=$ 0,709; persepsi $=0,712$; pembelajaran $=0,719$; sikap $=0,711$; pembelian kembali $=0,860$ ) . Dengan demikian kuesioner yang disusun ini dipastikan dapat digunakan untuk pengumpulan data selanjutnya.

Teknik Analisis Data

Analisis data dalam penelitian ini menggunakan analisis regresi berganda. Sebagai variabel dependen (Y) adalah keputusan pembelian kembali. Variabel independennya adalah motivasi (X1), persepsi (X2), pembelajaran (X3), dan sikap (X4). Analisis didahului dengan uji 
asumsi klasik regresi berganda. Pengujian hipotesa dilakukan melalui uji statistik yaitu uji $F$ (secara keseluruhan) untuk mengetahui apakah variabel independen secara keseluruhan dapat digunakan untuk menjelaskan variabel dependen, dan uji † (secara parsial) untuk mengetahui variabel independen yang mana dari motivasi, persepsi, pembelajaran, dan sikap yang mempengaruhi secara signifikan keputusan pembelian kembali (variabel dependen). Juga dihitung angka R-Square untuk mengukur kemampuan variabel-variabel independen dalam menjelaskan variasi variabel dependen.

\section{HASIL DAN PEMBAHASAN}

Uji Asumsi Klasik

Uji asumsi klasik yang lazim dilakukan untuk regresi berganda yang terdiri dari uji multikolinieritas, homoskedastisitas, dan normalitas memberikan hasil yang memenuhi semuanya. Uji multikolinieritas dengan menggunakan nilai VIF (variance inflation factors) memberikan nilai di bawah 10 untuk semua variabel yang menunjukkan tidak terjadi multikolinieritas. Selanjutnya uji homoskedastisitas dengan menggunakan scatter plot memberikan hasil berupa titik-titik yang menyebar di atas dan di bawah angka nol dari sumbu $Y$, yang berarti adanya esaman vatriasn dan tidak terjadi heteroskedastisitas. Uji normalitas melalui normal probability plot memberikan hasil berupa penyebaran data di sekitar garis diagonal dan mengikuti garis diagonal yang berarti dipenuhinya asumsi normalitas.

Uji F

Output statistik uji F disajikan pada Tabel 2. Nilai F-hitung yang tertera dalam Tabel 2 adalah sebesar 7,189 dengan tingkat signifikansi 0,000 . Nilai probabilitas $(0,000)$ yang lebih kecil dari 0,05 menunjukkan bahwa model regresi dapat dipakai untuk memprediksi keputusan pembelian kembali. Paling tidak terdapat satu variabel independen yang mempengaruhi variabel dependen (keputusan pembelian kembali). Dengan demikian dapat dikatakan bahwa psikologi konsumen mempengaruhi keputusan pembelian kembali produk BlackBerry.

Tabel 2

Uji-F ANOVA(b)

\begin{tabular}{|rl|r|r|r|r|l|}
\hline \multicolumn{1}{|c|}{} & \multicolumn{1}{c|}{$\begin{array}{c}\text { Sum of } \\
\text { Sodel }\end{array}$} & Squares & Df & \multicolumn{1}{c|}{$\begin{array}{c}\text { Mean } \\
\text { Square }\end{array}$} & \multicolumn{1}{c|}{ F } & Sig. \\
\hline 1 & Regression & 356,669 & 4 & 89,167 & 7,189 &, 000 (a) \\
& Residual & 2418,686 & 195 & 12,404 & & \\
& Total & 2775,355 & 199 & & & \\
\hline
\end{tabular}

a Predictors: (Constant), Sikap, Pembelajaran, Motivasi, Persepsi 
b Dependent Variable: Keputusan Pembelian Kembali

Nilai R square dalam analisis ini adalah sebesar 0,129 (Tabel 3), yang artinya $12,9 \%$ dari keputusan pembelian kembali dapat diprediksi dari keempat variabel independen yang terdapat dalam model tersebut, yaitu variabel motivasi, persepsi, pembelajaran, dan sikap. Sisanya $87,1 \%$ dijelaskan oleh variabel lain yang tidak diteliti dalam penelitian ini.

Tabel 3

Nilai $\mathrm{R}^{2-}$ Model Summary

\begin{tabular}{|l|r|r|r|r|}
\hline Model & $R$ & R Square & Adjusted R Square & $\begin{array}{c}\text { Std. Error of the } \\
\text { Estimate }\end{array}$ \\
\hline 1 &, $358(a)$ &, 129 &, 111 & 3,522 \\
\hline \multicolumn{2}{|r|}{ a Predictors: (Constant), Sikap, Pembelajaran, Motivasi, Persepsi }
\end{tabular}

Tabel 4 menyajikan parameter dari Uji t. Berdasarkan nilai † dan angka signifikansi pada Tabel 4, terlihat bahwa ternyata hanya terdapat satu variabel independen yang pengaruhnya signifikan terhadap keputusan pembelian kembali yaitu sikap. Sedangkan tiga variabel lainnya yaitu motivasi, persepsi, dan pembelajaran tidak terbukti mempengaruhi keputusan pembelian kembali produk BlackBerry secara signifikan. Berdasarkan nilai beta pada tabel 4, dapat disusun persamaan regresi sebagai berikut:

$$
Y=3,335+0,097 X_{1}+0,102 X_{2}+0,053 X_{3}+0,353 X_{4}
$$

Dimana $Y$ adalah keuputusan pembelian kembali, X1 adalah motivasi, $X 2$ adalah persepsi, X3 adalah pembelajaran, dan X4 adalah sikap.

Tabel 4

Uji † Coefficients (a)

\begin{tabular}{|c|c|c|c|c|c|c|}
\hline \multicolumn{2}{|c|}{ Model } & \multicolumn{2}{|c|}{$\begin{array}{c}\text { Unstandardized } \\
\text { Coefficients }\end{array}$} & \multirow{2}{*}{$\begin{array}{c}\text { Standardized } \\
\text { Coefficients } \\
\text { Beta }\end{array}$} & \multirow{2}{*}{$\frac{t}{B}$} & \multirow{2}{*}{$\frac{\text { Sig. }}{\text { Std. Error }}$} \\
\hline & & B & Std. Error & & & \\
\hline \multirow[t]{5}{*}{1} & (Constant) & 3,335 & 2,880 & & 1,158 & ,248 \\
\hline & Motivasi & ,097 & , 102 & ,067 &, 952 & ,342 \\
\hline & Persepsi & , 102 & 11 & , 070 &, 913 &, 362 \\
\hline & $\begin{array}{l}\text { Pembelajar } \\
\text { an }\end{array}$ & ,053 & 127 & ,031 & ,421 & ,674 \\
\hline & Sikap & ,353 & ,084 & 297 & 4,186 & ,000 \\
\hline
\end{tabular}

a Dependent Variable: Keputusan Pembelian Kembali

Hasil penelitian menunjukkan bahwa dari keempat faktor psikologi konsumen yang merupakan variabel inependen, hanya sikap yang mempengaruhi secara signiffikan terhadap keputusan pembelian kembali, dengan nilai $\dagger$ sebesar 4,816. Artinya sikap yang positif terhadap produk BlackBerry akan meningkatkan kecenderungan pembelian kembali 
produk BlackBerry. Hasil ini sesuai dengan prediksi awal yang dituangkan dalam hipotsesis penelitian (H4). Semakin positif sikap pengguna terhadap produk BlackBerry maka semakin tinggi kemungkinan untuk melakukan pembelian kembali produk BlackBerry. Demikain sebaliknya semakin negatif sikap pengguna BlackBerry terhadap produk BlackBerry maka kemungkinan akan melakukan pembelian kembali produk BlackBerry juga menurun. Hasil ini memberikan implikasi akan perlunya pemasar BlackBerry untuk tetap menjaga dan meningkatkan sikap positiff konsumen terhadap produk BlackBerry.

Hasil penelitian juga memperlihatkan bahwa ternyata motivasi, persepsi, dan pembelajaran tidak memberikan pengaruh yang signifikan terhadap keputusan pembelian kembali produk BlackBerry. Artinya dalam kasus ini, tinggi rendahnya ketiga variabel ini tidak memberikan dampak terhadap tinggi rendahnya kemungkinan konsumen untuk membeli kembali produk BlackBerry. Implikasinya, apabila pemasar memiliki sumberdaya yang terbatas, maka dalam konteks penelitian ini sebaiknya sumberdaya ini hanya diarahkan dan dialokasikan untuk mengubah sikap konsumen ke arah yang lebih positif.

Hasil penelitian yang tidak sesuai dengan prediksi ini diperkirakan terjadi karena walaupun sampel dalam penelitian ini adalah semuanya pengguna BlackBerry namun mereka berasal dari kalangan yang majemuk dengan uang saku yang bervariasi mulai dari Rp. 500 ribu sampai dengan lebih dari Rp. 2 juta per bulan. Latar belakang ini menyebabkan bervariasinya motivasi mereka sedangkan kemungkinan mereka untuk melakukan pembelian kembali relatif sama. Demikian juga mereka memiliki perspepsi terhadap BlackBerry yang cenderung bervariasi. Diperkirakan mereka menggunakan berbagai tipe BlackBerry yang memiliki perbedaan harga yang cukup tinggi (dari sekitar Rp. 2 jutaan sampai dengan Rp. 6 jutaan, dan menggunakan BlackBerry baru maupun bekas- second hand dengan perbedaan harga yang cukup signifikan). Sebagian besar dari mereka diperkirakan juga belum menganggap bahwa BlackBerry merupakan merk yang mapan dikarenakan merk ini relatif masih baru dan baru beberapa tahun terakhir ini dikenal luas di berbagai kota besar di Indonesia.

\section{SIMPULAN}

Hasil penelitian menunjukan bahwa psikologi konsumen mempengaruhi keputusan pembelian kembali produk BlackBerry. Sikap merupakan elemen dalam psikologi konsumen yang mempengaruhi keputusan pembelian kembali secara signifikan. Hasil ini memberikan arahan kepada pemasar produk BlackBerry untuk memberikan perhatian yang maksimal terhadap sikap konsumen terhadap BlackBerry. 
Penelitian ini tidak mendata apakah responden membeli BlackBerry baru ataukah bekas. Demikian juga tidak didata jenis BlackBerry yang mereka gunakan. Kedua aspek ini diduga juga ikut memberi dampak pada hasil penelitian. Penelitian selanjutnya disarankan untuk mendata secara tepat kedua aspek ini. Penelitian ini menggunakan mahasiswa sebagai responden yang tentunya berdampak pada terbatasnya generalisasi hasil penelitian. Untuk memperluas generalisasi hasil penelitian, disarankan pada penelitian selanjutnya untuk menggunakan sampel dari kalangan professional (non mahasiswa) yang saat ini terlihat banyak menggunakan BlackBerry dalam aktivitas mereka sehari hari.

\section{DAFTAR REFERENSI}

Akir, Oriah, \& Othman, M.N. 2010. Consumers' shopping behaviour pattern on selected consumer goods: Empirical evidence on Malaysian consumers. Journal of Business \& Policy Research Volume 5/1, 123 - 157

Aritonang R., Lerbin. 2007. Riset pemasaran. Bogor : Ghalia Indonesia

Blackwell, Roger D., Miniard, Paul W., \& Engel, James F. 2001. Consumer behavior, $9^{\text {th }}$ Eds. Orlando-Florida: Harcourt Inc

Goodwin, R., \& Ball, B. 2003. What marketing wants the CEO to know. Marketing Management 12/5,18-23.

Hawkins, Del I., Mothersbaugh, David L., \& Best, Roger J. (2007). Consumer Behavior: Building Marketing Strategy. $10^{\text {th }}$ Edition. New York: McGraw-Hill/Irwin

Kim, D.J., Ferrin, D.L., \& Rao, H.R. 2003. A Study of the effect of consumer trust on consumer expectations and satisfaction: the Korean experience. In Proceedings of the 5th International Conference on Electronic Commerce, Pittsburgh, Pennsylvania, 310-315.

Kontan-Online, 2010. XI Rilis BlackBerry Gaul (Diupdate 1 Februari 2010) Tersedia di : http://www.kontan.co.id [Diakses pada 28 Juli 2010]

Kotler, Philip \& Keller, Kevin L. 2006. Marketing Management, 13 $3^{\text {th }}$ Edition. New Jersey: Pearson Education.

Michael, Solomon R. 2009. Consumer Behavior, 8th Edition. New Jersey: Pearson Education.

Mowen, John C., \& Minor, Michael. 2002. Consumer Behavior, $6^{\text {th }}$ Edition, New Jersey: Prentice Hall.

Schiffman, Leon. G., \& Kanuk, Leslie Lazar. 2007. Cosumer Behavior, Eight Edition. New Jersey: Pearson Education.

Swa-Online, 2010. Kerja Sama Indosat dan RIM Membaik. (Diupdate 27 Juli 2010) Tersedia di: http://www.swa.com [Diakses pada 28 Juli 2010] 
Jurnal Manajemen Teori dan Terapan | Tahun 3, No. 2, Agustus 2010| Bunga Geofanny Fredereca dan Chairy

Swa-Online, 2010. Dinamika Merek-merek Paling Bernilai (Diupdate 15 Juli 2010) Tersedia di: http://www.swa.com [Diakses pada 28 Juli 2010] 